\title{
A saúde dos povos indígenas: a declaração de Kuching para ação
}

\author{
Aprovada no $6^{\circ}$ Congresso Mundial de Saúde Rural
}

Santiago de Compostela, Espanha, 2003

WONCA Working Party on Rural Practice

Ademais da Declaração de Durban e da declaração de Kuching de 1999, que convocam para uma Iniciativa Global de Saúde Para Toda a Populaçáo Rural, nós, como profissionais de saúde das zonas rurais de todo o mundo, que estivemos presentes à sexta Conferência Mundial WONCA sobre Saúde Rural em Santiago de Compostela, Espanha, notamos com preocupaçáo que:

- A despeito da diversidade cultural e étnica, existem notáveis semelhanças entre os problemas, disparidades na saúde e interesses dos povos indígenas no mundo todo.

- O estado de saúde dos povos indígenas em muitos países é significativamente pior do que aquele da população como um todo.

- Os povos indígenas representam as mais marginalizadas e mais pobres subpopulaçóes do mundo.

- Muitos dos problemas de saúde dos povos indígenas são decorrentes das condiçóes socioeconômicas precárias.

- A realocação forçada de povos indígenas sem consulta ou consentimento informado tem um efeito danoso sustentado sobre a saúde e bem-estar cultural dessas comunidades e seus membros.

\section{Consequentemente, afirmamos que:}

\section{Definição de Povos Indígenas}

O termo "indígena" se refere àqueles que, enquanto conservando total ou parcialmente suas línguas, organizações e estilos de vida tradicionais, que os distinguem da sociedade dominante, ocuparam uma área particular antes da chegada de outros grupos populacionais. 


\section{Definição de autodeterminação}

A Carta das Nações Unidas, a Convenção Internacional sobre Direitos Econômicos, Sociais e Culturais e a Convenção Internacional sobre Direitos Civis e Políticos afirmam a importância fundamental do direito de autodeterminaçáo de todos os povos.

A. Autodeterminação é o poder que faz com que os povos possam livremente determinar seu status político e buscar o próprio desenvolvimento econômico, social e cultural².

B. Os Povos Indígenas, como uma forma específica de exercitarem o direito de autodeterminação, têm o direito à autonomia ou autogoverno em matérias relacionadas aos assuntos internos e locais, incluindo cultura, religiáo, educaçáo, informação, comunicação, saúde, habitação, emprego, bem-estar social, atividades econômicas, gerenciamento de terras e recursos, meio ambiente e ingresso de não membros, bem como aos meios para financiar essas funçôes autônomas.

\section{Direitos}

Os direitos dos Povos Indígenas foram afirmados na Declaração Universal dos Direitos Humanos. ${ }^{3}$

A. Saúde equânime para os Povos Indígenas é um direito humano básico.

- Para atingir isto, são necessários esforços e recursos adicionais.

B. Parceria, compromisso e vontade política são necessários para melhorar o estado de saúde e bem-estar dos Povos Indígenas.

- Parcerias exigem participação, em que há reconhecimento de interdependência, necessidade de integridade e equilíbrio de poder no relacionamento entre todos os participantes.

C. A saúde e o bem-estar das Famílias Indígenas requerem atenção especial.

- Uma criança nascida na pobreza, exposta a viver e morar em condiçóes inadequadas e com pouco acesso à alimentação perpetua o ciclo de pobreza e predispóe à doença crônica e à incapacidade.

- Toda criança tem o direito a um meio ambiente que favoreça seu desenvolvimento físico, espiritual, moral e social. ${ }^{4}$

D. Os Povos Indígenas têm direito a serviços de saúde culturalmente apropriados, de preferência em sua própria língua.

- Todos os povos têm o direito e o dever de participar individualmente e coletivamente no planejamento e implementação do seu modelo de atenção à saúde. ${ }^{5}$

- O controle social indígena na saúde, particularmente nas açôes de atenção primária ${ }^{6}$, fornece o suporte para uma prestação adequada e aceitável.

- Profissionais da saúde e governos devem reconhecer a importância das terapias alternativas indígenas, incluindo os curandeiros e os remédios tradicionais.

\section{Controle Social Indígena}

A. É essencial que os Povos Indígenas estejam envolvidos no aprimoramento de seu estado de saúde através de iniciativas públicas e privadas.

- Os povos Indígenas devem estar incluídos na formulação, execução e avaliação dos serviços de saúde. ${ }^{7}$

B. Os Povos Indígenas devem sempre ser envolvidos em Fóruns nacionais e internacionais que tratam de questôes de saúde rural.

C. Povos Indígenas devem ser educados e treinados como profissionais de saúde. 


\section{Envolvimento dos profissionais da saúde}

A. Profissionais da saúde têm o dever de defender políticas e programas que apontarão os determinantes sociais, ambientais e econômicos de maneira a aprimorar o estado de saúde dos Povos Indígenas.

B. Profissionais da saúde têm o dever de defender políticas e programas de outras áreas que afetam os determinantes de saúde indígena.

C. Os profissionais da saúde devem receber educação e treinamento em saúde indígena, incluindo competência cultural, e negociar políticas e programas que afetarão os determinantes de saúde indígena.

- Povos Indígenas devem ser incluídos na formação, execução e avaliação da educação, incluindo esquemas de treinamento vocacional. ${ }^{8}$

\section{Recomendações à WONCA}

Que a WONCA concorda que a Declaração de Kuching para Ação 2003 revisada seja recomendada para ação das Nações Unidas e Governos.

Esta declaração deve ser usada na sua totalidade. Nenhum elemento individual desta declaração deve ser considerado isoladamente ou usado para negar qualquer dos princípios destacados neste documento.

\section{Referências}

1. Organização Internacional do Trabalho, 1989.

2. Resumo da Declaração Sobre os Direitos dos Povos Indígenas.

3. Declaração Universal dos Direitos Humanos 1948.

4. Artigo 27 da Convenção sobre os Direitos da Criança.

5. Alma Ata WHO 1978.

6. Organização Internacional do Trabalho 1989.

7. Organização Internacional do Trabalho 1989.

8. Organização Internacional do Trabalho 1989.

Tradução para a versão brasileira: Rodrigo Silveira

Rio de Janeiro: SBMFC, 2012. 